\title{
SPATIAL-TEMPORAL CHARACTERISTIC OF DROUGHT NORTHERN NIGERIA
}

\section{ACHUGBU IFEANYI CHUKWUDI AND BALOGUN IFEOLUWA ADEBOWALE}

(Received 1 November 2017; Revision Accepted 9 February 2018)

\begin{abstract}
This paper examines the spatial and temporal characteristics of droughts during the rainy season (May-October) for 1965-2010 over northern Nigeria using monthly rainfall data from station rain gauges. The spatial distribution of rainfall is identified by Standardized Precipitation Index (SPI), which also characterizes specific temporal drought events. Mann-Kendall trend test is applied to analyze the changes in the drought trend and also to confirm the significance of the observed trends. The results of the analysis show major changes in the drought characteristics in northern Nigeria during the major dry episodes (1973-1983) and major wet episodes (1996-2010). For the period 1965-1985, all the stations showed a decreasing trend both in 3 and 6 months time scales. In contrast, $87.5 \%$ of the stations showed an increasing trend for the period 1985-2010, with Maiduguri, Nguru, Kano, Katsina and Yelwa showing significant increases, the prolonged dry spell in the 1970's and 1980's was shown clearly in some of the analyses. A large number of further observations would be required to put some of these findings on a finer basis for the Sahelian drought characterization. It is recommended that agricultural organizations and disaster management parastatals should be pro-active in drought adaptation and mitigation planning.
\end{abstract}

KEYWORDS: Standardized Precipitation Index, Spatial, Temporal, drought, Mann-Kendall, trend.

\section{INTRODUCTION}

Drought is very common in most countries of the world, particularly those located in the arid and semiarid areas (Shahid and Hazarika, 2010; Wang et al., 2012a). Drought is defined as a "period of insufficient rainfall either in time or in space". It is caused by low rainfall, often associated with increased evaporation rates. This results in crop failure, enough to cause a severe shortage of food in a rural population (Betterton and Gadzama, 1987, Abdullahi, et al, 2006). The socioeconomic and environmental impacts of drought affect many sectors of African economy (Olatunde and Aremu, 2013). Each year large areas and populations of the Sahel region of Nigeria have suffered from the impacts of drought (Oladipo, 1993; Adefolalu, 1986).Climate change projections show a likely associated increase in dry spell length and frequency of drought occurrence gradually spread southward especially to the Guinea Coast of Nigeria (Aremu and Olatunde, 2013). Drought can lead to an economic crisis, as rainfall is the main source of water for agricultural production, which is the main source of export in the area.

There is an urgent need to adapt to the negative impacts of drought, but awareness is limited, especially on how tropospheric circulation can be connected to drought that typically has a larger spatial variability (Fleig et al., 2010). This requires an adequate description of the spatial and temporal analysis of drought characteristics over large region. Droughts are derived preferably from observations (e.g. Lins and Slack, 1999; Hisdal, et al., 2001), but data availability is limited which brings about a high uncertainty (Nauman et al., 2014). A detail statistical analysis enhances our understanding of how droughts evolve at large scales. We focus attempt to identify large scale, space-time patterns in droughts. Various approaches in previous studies on the spatial and temporal development of drought like Sharma(1997)have concentrated on the use of rainfall series as a single hydrological input in their drought studies. Sheffield et al. (2009) described the spatial extent of soil moisture drought, computed for the whole globe and for 20 locations over the world. This kind of spatial drought analysis cannot clearly show and characterize specific spatial events. This paper aims at further attempt on the spatial and temporal development of drought on a local scale. The results presented in this paper are the basis for further works on global drought analysis. The approach is with the use of Standardized Precipitation Index (SPI), which has been widely applied in drought studies (McKee et al., 1993).

\section{DATA AND METHODOLOGY}

The region of Nigeria where the study was conducted (Figure1) lies between latitude $10^{\circ}-14^{\circ} \mathrm{N}$ and longitude $3^{\circ}-14^{\circ} \mathrm{E}$, is a vast aggregate of landmass with more than 100 million inhabitants. Different Agro-Ecological Zones (AEZs) can be identified within Nigeria (Ifabiyi and Ojoye, 2013). Achugbu Ifeanyi Chukwudi, Department of Water Resources Management \& Agrometeorology, Federal University, Oye-Ekiti, Ekiti State Nigeria.

Balogun Ifeoluwa Adebowale, Department of Meteorology and Climate Science, Federal University of Technology, Akure, Ondo State Nigeria. 


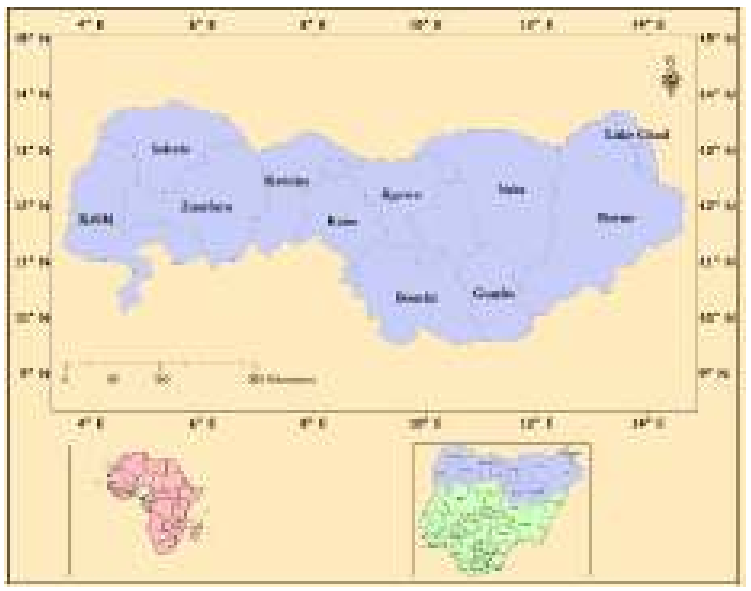

Figure 1: Map of the Study Area

On the basis of the zoning of annual precipitation, length of the growing period, vegetation and agricultural potential, Nigeriahas been classified into four agro-ecological zones. These are: Sahel zone, Sudan savanna zone, Guinea-savanna zone and Equatorial forest zone (FAO 1978). The Study area covers the Sudano-Sahelianzone as represented by Sokoto, Kebbi, Zamfara, Katsina, Kano, Jigawa, Bauchi, Yobe, Borno, Gombe and Adamawa states, located between latitudes $10^{\circ}-14^{\circ} \mathrm{N}$. The region experiences two distinct seasons namely: dry season with dominant northeast winds (October-April) and wet season (MaySeptember) with strong southwest winds. The region undergoes wet and dry periods, resulting in widespread heavy rainfall in some areas, while other locations receive very low rainfall. The rainfall variability and extremes (drought) are often a result of the EL-Nino southern oscillations (ENSO), particular Atlantic gradient in sea surface temperatures(Kidson 1977; Oladipo 1993). The rainfall $(\mathrm{mm})$ data for the period of MayOctober, 1965-2010 is obtained from the Nigeria Meteorological Agency. Seasonal rainfall data series of Northern Nigeria is derived from monthly rainfall data of 9 stations located in Maiduguri, Nguru, Kano, Katsina, Potiskum, Gusua, Sokoto, Bauchi and Yelwa stations. Mean monthly and annual Standard Deviation (SD) and Standardised Precipitation Index (SPI) are adequately computed.

The SPI shows the amount of fluctuation in rainfall observed over a long period of time from the mean values. The SPI is an index of drought, showing almost same pattern of fluctuations in the yearly water storage for crop cultivation. For agricultural practices, it may be more crucial statistics for small locations than in either very dry areas, where farming activities have adapted to variability, or relatively low inter-annual variability in wet areas. The SPI is computed by the following equation, which takes into account the precipitation record for a location and chosen period (months or years). The record is fitted to a probability distribution, which is then transformed into a normal distribution so that the mean SPI for the location and period is zero. The index is negative for drought and positive for non-drought conditions.
$S P I=\frac{\mathrm{X}_{i j}-\overline{\mathrm{X}}_{i}}{\sigma_{i}}$

Where $X_{i j}$ is the rainfall for the $i^{\text {th }}$ station and $j^{\text {th }}$ observation, $\bar{X}_{i}$ is the mean rainfall for the $i^{\text {th }}$ station and $\sigma_{i}$ is the standard deviation for the $i^{\text {th }}$ station. SPI is used in this study because of its versatility and only precipitation data is the required input data. It is not complex as many other drought indices, but can provide early warning of drought and also in the assessment of drought severity (WMO 2012).

The results of the computed SPI were presented graphically and spatially with ARCGIS software using the Inverse Distance Weighted (IDW) interpolator. This interpolation method was used because of the simplicity of its principle, the lack of turnable parameters and also its ability to work in $\mathrm{N}$ dimensional space. The IDW algorithm is not as complex as the Kriging method and it gives realistic results for many kinds of data set. Temporal changes in the monthly, seasonal and annual rainfall are also analyzed by Mann-Kendall test to confirm the significance of the observed trends. MannKendall test is a statistical test widely used for the analysis of trend in climatologic and hydrologic time series (Mavromatis and Stathis 2011; Yue and Wang 2004). There are two advantages of using this test in this study. First, it is a non-parametric test and does not require the data to be normally distributed, suiting perfectly for the nature of distribution observed in the study area. Second, the test has low sensitivity to abrupt breaks due to non-homogeneous time series. In this test, the number of annual values in the studied data series is denoted by ' $n$ '. If ' $n$ ' is at least 10 , the normal approximation test is used. However, if there are several tied values (i.e. equal values) in the time series, it may reduce the validity of the normal approximation when the number of data values is close to 10. First, the variance (S) is computed by the following equation, which takes into account that ties may be present:

$S=\sum_{k=1}^{n-1} \sum_{j=k+1}^{n} \operatorname{sgn}\left(x_{j}-x_{k}\right)$ 2 
$\operatorname{sgn}\left(x_{j}-x_{j}\right)=\left\{\begin{array}{ll}1 & \text { if } x_{j}-x_{k}>0 \\ 0 & \text { if } x_{j}-x_{k}=0 \\ -1 & \text { if } x_{j}-x_{k}<0\end{array} \quad \ldots \ldots \ldots \ldots \ldots \ldots \ldots \ldots . .3\right.$

Where $\mathrm{n}$ is the number of data, $\mathrm{x}$ is the data point at times $\mathrm{j}$ and $\mathrm{k}, \mathrm{j}>\mathrm{k}$. The variance of $\mathrm{S}[\operatorname{VAR}(\mathrm{S})]$ is calculated using the formula;

$\operatorname{VAR}(S)=\frac{1}{18}\left[n(n-1)(2 n+1)-\sum_{q=1}^{p} t_{q}\left(t_{q}-1\right)\left(2 t_{q}+5\right)\right] \ldots \ldots \ldots \quad 4$

Where $\mathrm{p}$ is the number of tied groups and $t_{q}$ is the number of data values in the $q^{\text {th }}$ group. The test statistic $Z$ is calculated thus using the values of $S$ and $\operatorname{VAR}(S)$;

$Z=\left\{\begin{array}{rr}\frac{S-1}{\sqrt{V A R(S)}} \text { if } S>0 \\ 0 \quad \text { if } S=0 \\ \frac{S+1}{\sqrt{V A R(S)}} \text { if } S<0\end{array}\right.$
At the $99 \%$ level of significance, the null hypothesis of no trend is rejected if $|Z|>2.575$; at $95 \%$ level of significance, the null hypothesis of no trend is rejected if $|Z|>1.96$; also at $90 \%$ level of significance, the null hypothesis of no trend is rejected if $|\mathrm{Z}|>1.645$. Additional details of the test can be discovered in Sneyers (1990). Also, the Climate Research Unit CRU Time Series TS data series used is a product from the University of East Anglia in England. The dataset contain monthly time series of precipitation and some other variables covering Earth's land areas for 1901-2015. The data set is gridded to $0.5 \times 0.5^{0}$ grid boxes, based on the evaluation of over 4000 individual weather station records. Details can be found in Harris et al. (2014).

\section{RESULTS AND DISCUSSIONS}

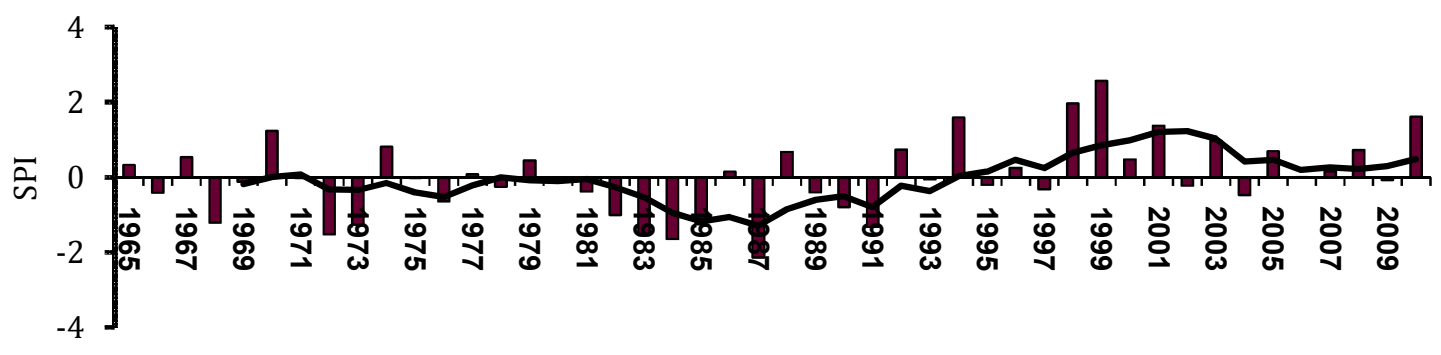

Figure 2: Time series (1965-2010) of 3-month SPI for 9 stations in the Study area.

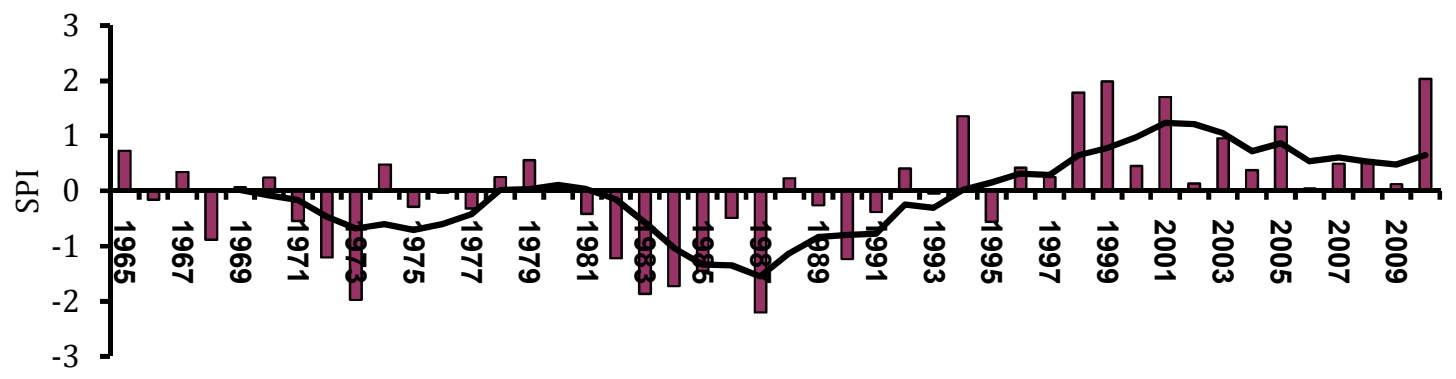

Figure 3: Time series (1965-2010) of 6-month SPI for 9 stations in the Study area.

The results of the analysis show many years of drought as categorized into near normal (NN)with SPI between 0.99 and -0.99 , moderate drought (MD)with SPI between -1 and -1.49 , severedrought (SD) with SPI between -1.5 and -1.99 , extreme drought (ED)with SPI from -2 and below, below average rainfall with SPI index between 0 and below, and above normal drought (AN) with SPI index below -0.99. The 3 month SPI analysis indicate short and medium term moisture condition while the 6-month SPI could be associated with unusual stream-flows and reservoir levels which depends on the region and time of year (WMO 2012). Figure 2, shows that there is shortage in short and medium term moisture condition which signifies the prevalence of meteorological drought years during the period of study. The area generally experienced about 25 years of below average rainfall between 1965 and 2010 and this is a clear indication that $54 \%$ of agricultural dependent rainfall for the years of study was ravaged by drought. From 1965 to 1995, series of drought years were prevalent with few wet years. Figure 3, shows the prevalence of unusual stream-flows and reservoir levels 
as the October SPI (6 months) revealed that the entire study area experienced about 20 years of 6-month below average rainfall condition during the years under investigation. Between 1966 and 1993, series of drought years with few non-drought years were observed, while the recent years (1996-2010) mostly served as recovery period from drought episodes, as the area generally experienced wet years as earlier recorded by Aremu and Olatunde(2013) and Buba(2010). The 5-yearmoving averages for both time scales showed two distinct drought episodes (the 1970's and 1980's) and a clear wet

(1996-2010).
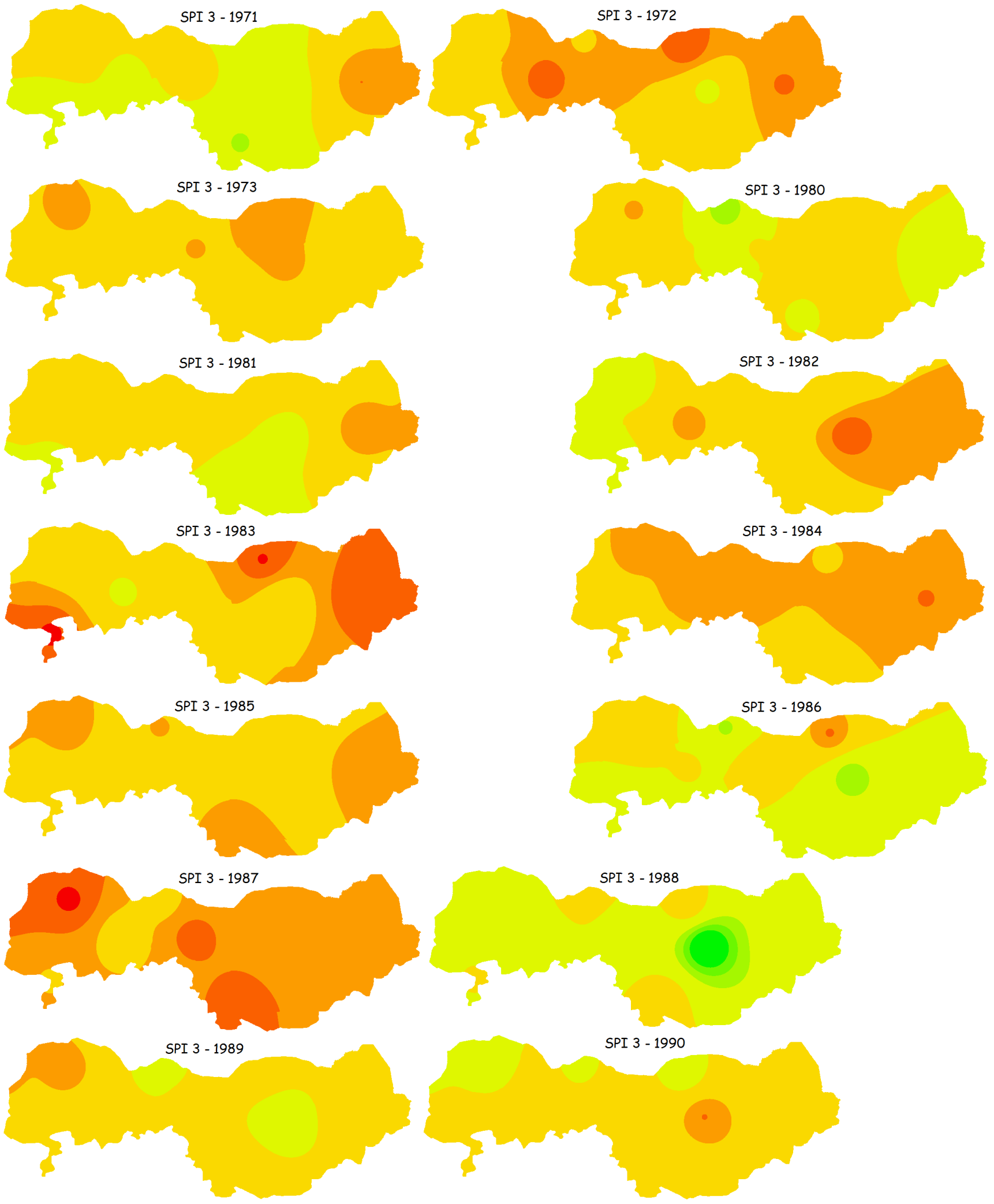


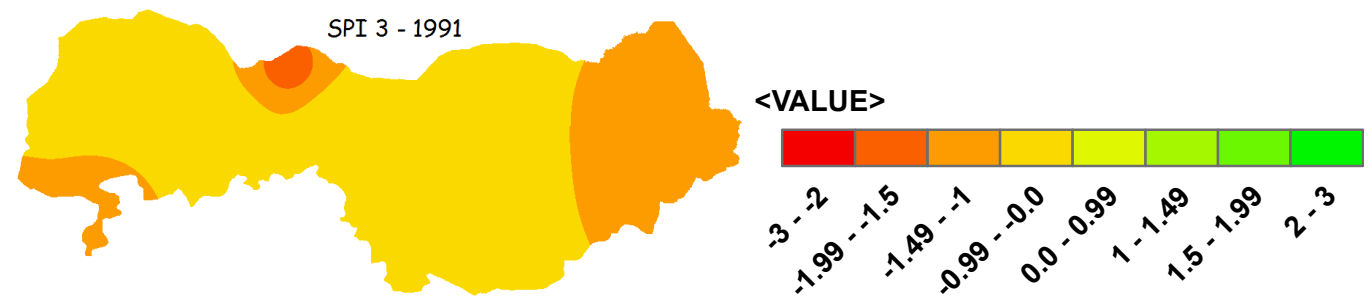

Figure 4: 3-months SPI spatial map of the study area for 1971-1973 and 1980-1991

The red color in the maps in figure 4 and 5 shows the most affected area and also area with the least and unstable rainfall within a particular year, while the green color shows the area least affected. The spatial maps were developed mainly for years with record of drought condition. From figure 4, the drought of the early 1970's was more severe in the eastern part of the area in 1971 but covered the entire area in 1972 and 1973, which
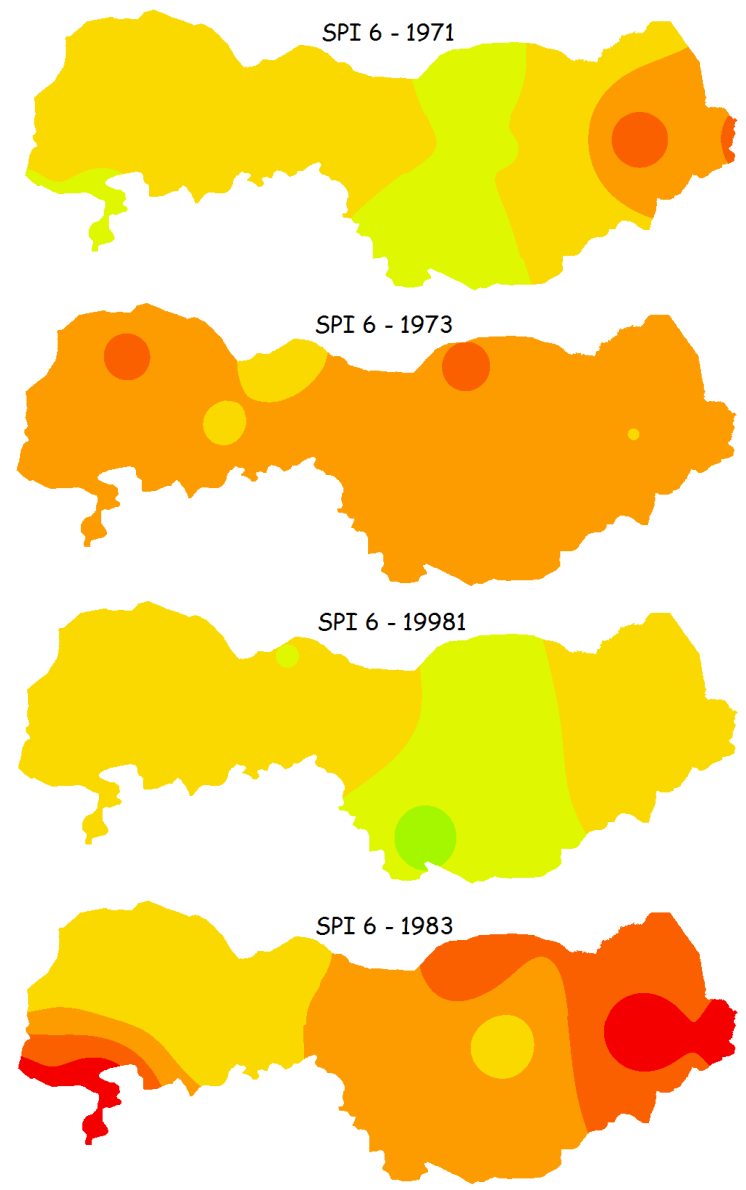

marked the end of the 1970's drought in the area. The 1980 's drought episode however re-surfaced in 1980 as it started mildly in Sokoto and Nguru, but intensified and went across the whole area in 1983, 1984 and 1985. It however subsided a little at the eastern part and around Yelwa and intensified again in 1987. This continued until it finally ended in 1992, which marked the end of the 1980's drought episode.
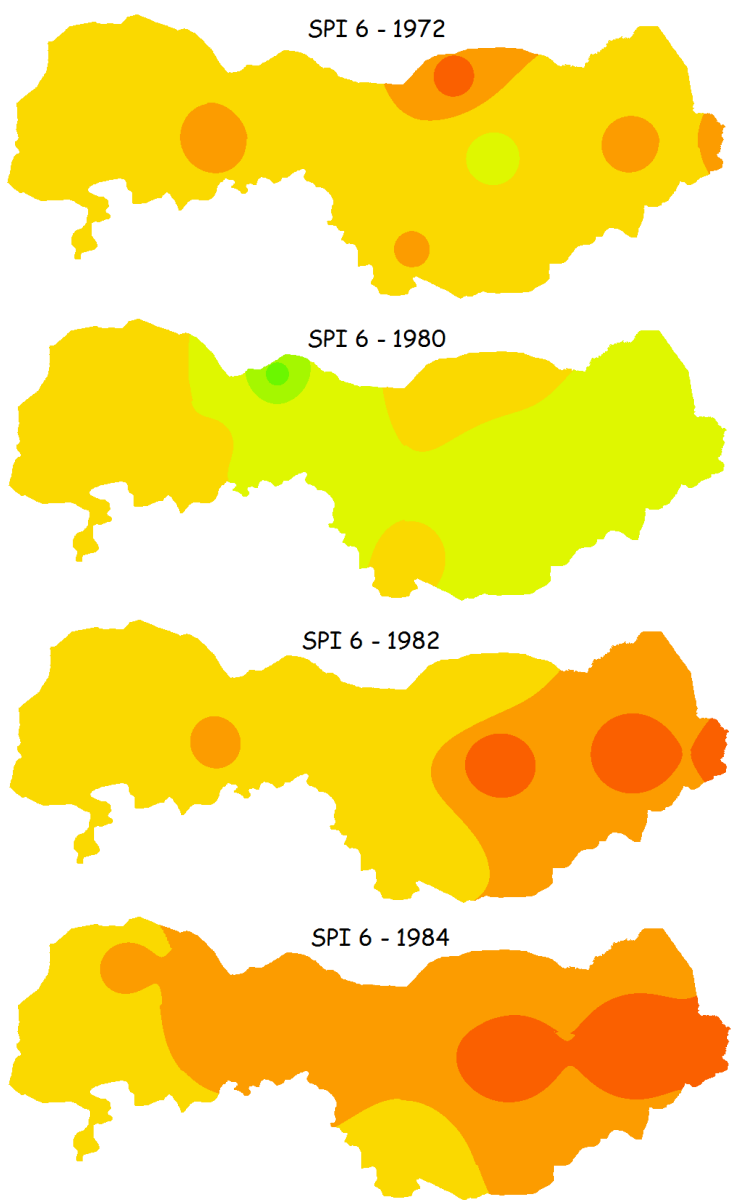

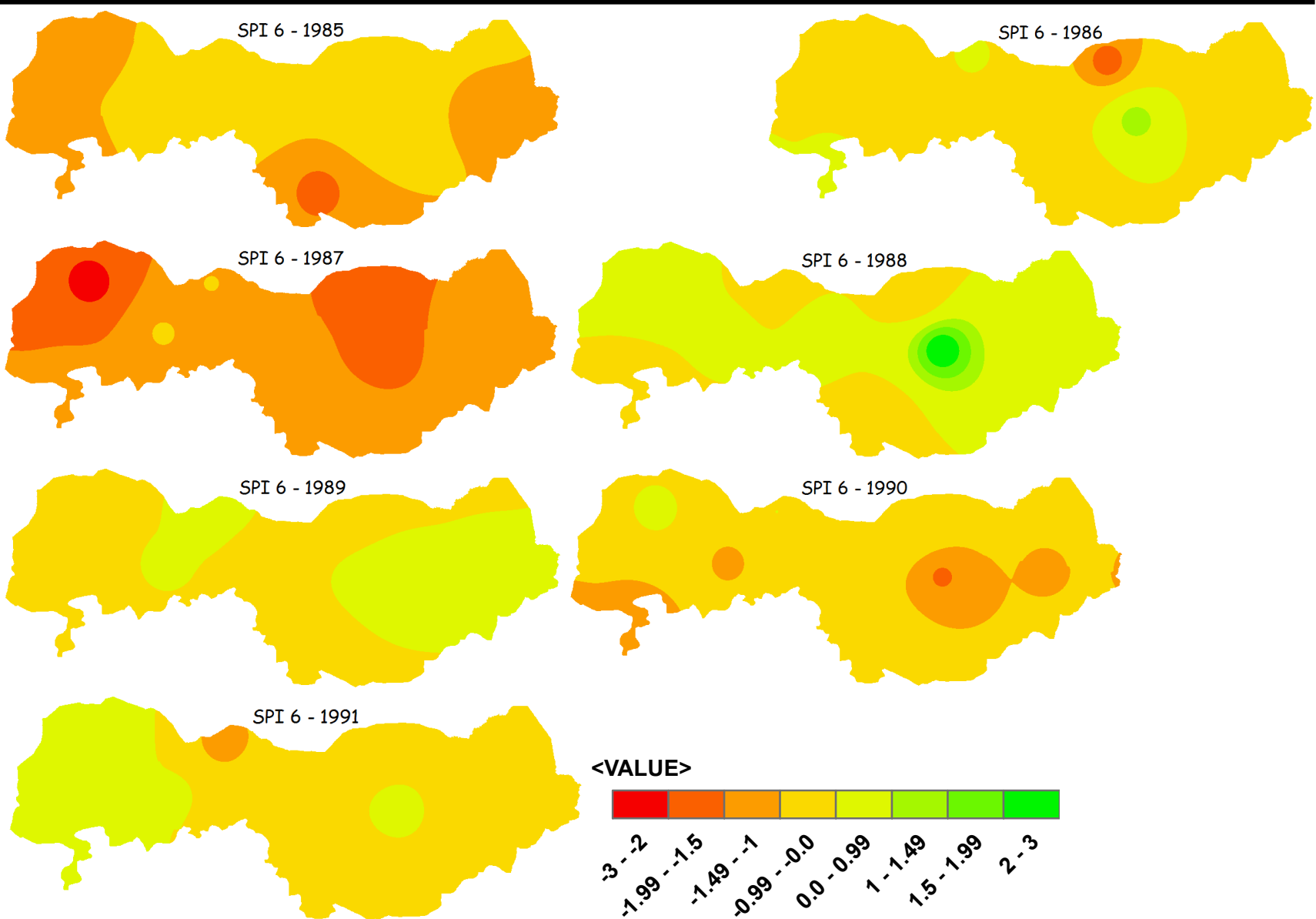

Figure 5: 6-month (May-Oct) SPI spatial map of the study area for 1971-1973 and 1980-1991

As regards the prevalence of unusual stream-flows and reservoir levels, figure 5 reveals that Maiduguri and Sokoto were mostly affected in 1971 until 1973 when the whole area experienced shortages in rainfall. The eighties drought was insignificant in 1980, but wentacross all the stations in 1982 and became severe in most of the area in 1983 (Ayoade 1988). It started subsiding in 1984 till in 1987 when it became severe and later continued till 1992, which marked the end. The remaining years of the late 90's to 2010 showed no defined drought episode, as most of the years were wet and moderate. Also, the haphazardly spatial representation of the result can be attributed to the systems that brought about instabilities in the West African sub-region.

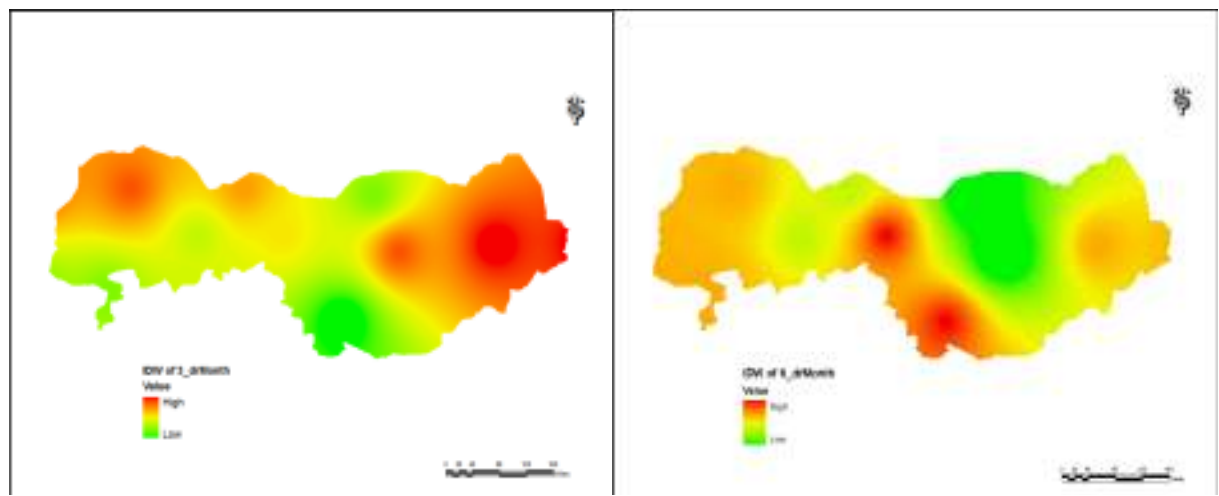

Figure 6: 3-month and 6-month time scale drought risk map for the study area

However, the resultant extreme, severe, and moderate occurrences in each of the stations in the study area were classified and drought frequency risk maps were generated for 3-month and 6- month time scales. It shows the presence of a high risk of severe and moderate drought situation in Maiduguri, Sokoto and
Potiskum for 3-month time scale, whereas Kano and Bauchi showed higher risk of more than near normal drought situations for the 6-month time scale. This by implication means that Maiduguri, Bauchi and Kano are more prone to shortfall in rainfall, which can be a threat to agricultural development. 


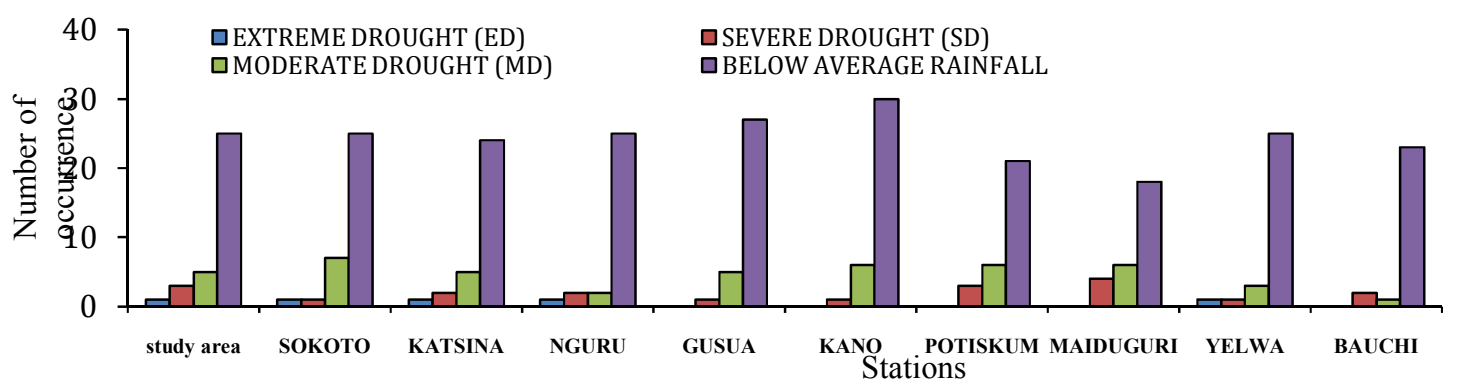

Figure 7: Number of drought occurrences for 3-month time scale

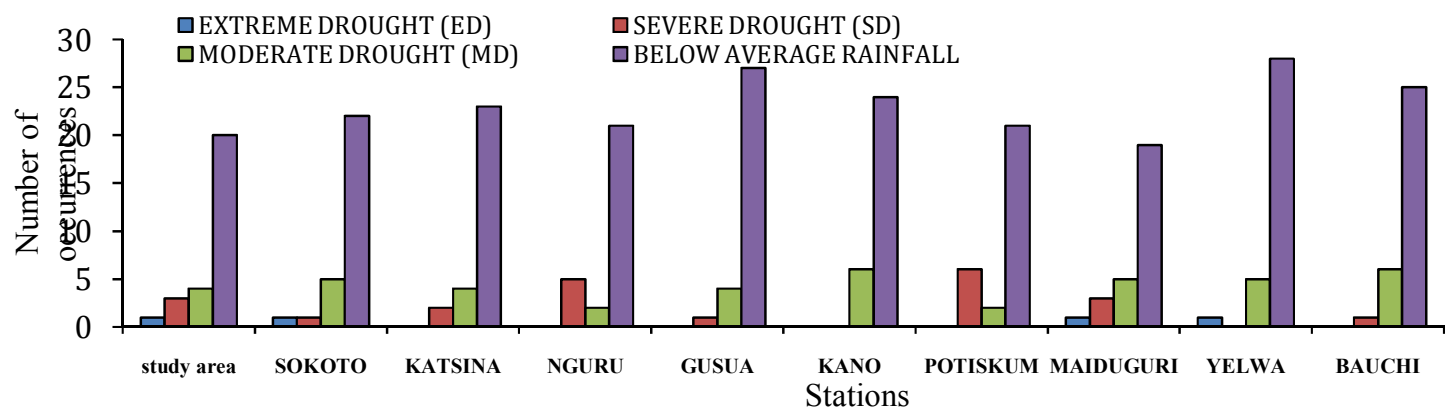

Figure 8: Number of drought occurrences for 6 months time scale

From figure 7, Kano generally showed the highest number of below average rainfall (30) while Maiduguri had the least (18). Maiduguri experienced the highest number of above normal drought condition while Bauchi had the least.From figure 8 , Yelwa had the highest number of below average rainfall (27) while Maiduguri had the least (19). Maiduguri experienced the highest number of above normal drought situation while Gusua had the least.

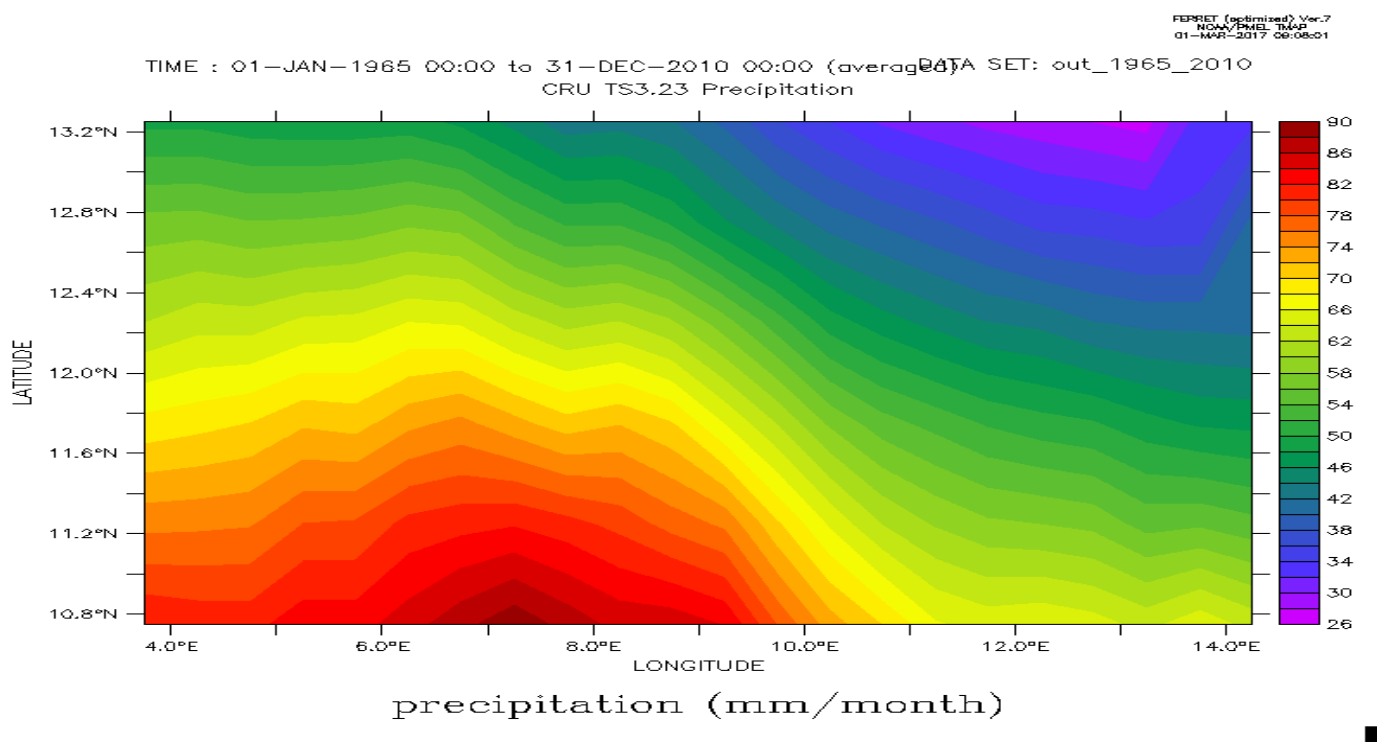

Figure 9: Spatial distribution of average precipitation over northern Nigeria

In other to complement the results, the map showing the spatial distribution of average precipitation data from Climate Research Unit (CRU)Time Series (TS) gridded dataset for the study area from January 1965 to December 2010 was plotted. On average, the North Eastern part of the study area shows the least average rainfall, while the southwestern part has the highest average rainfall. Though many literature have pinpointed this, but special attention have not been implemented over this area especially the lake Chad region. 
Also, to check the trend of the rainy season rainfall, 3 and 6 months periods were analyzed using the Mann-Kendal trend test which showed different levels of positive and negative trends as shown in Table 1. The 3month trend test for 1965-2010 showed an increasing trend for all the station except for Katsina. Also, Kano and Yelwa showed a significant increasing trend, (as earlier reported by Achugbu and Anugwo 2016) while others were not significant.

Table 1: Test $Z$ values from Mann-Kendall trend test for 3 and 6 months' rainfall

\begin{tabular}{|c|c|c|c|c|c|c|c|c|}
\hline & \multicolumn{4}{|c|}{3 months } & \multicolumn{4}{|c|}{6 months } \\
\hline Station & $\begin{array}{l}1965- \\
2010\end{array}$ & $\begin{array}{l}1965- \\
1985\end{array}$ & $\begin{array}{l}1975- \\
1995\end{array}$ & $\begin{array}{l}1985- \\
2010\end{array}$ & $\begin{array}{l}1965- \\
2010\end{array}$ & $\begin{array}{l}1965- \\
1985\end{array}$ & $\begin{array}{l}1975- \\
1995\end{array}$ & $\begin{array}{l}1985- \\
2010\end{array}$ \\
\hline Maiduguri & 1.25 & $-2.08^{*}$ & -0.75 & $1.98^{*}$ & 1.46 & -1.3 & -1.18 & $3.04^{* *}$ \\
\hline Nguru & 0.23 & -1.00 & -0.94 & $1.81^{*}$ & -0.42 & $-1.78^{*}$ & -1.54 & $2.42^{*}$ \\
\hline Kano & $3.35^{\star *}$ & -1.00 & -0.94 & 1.81 & $3.39^{* *}$ & $-1.78^{*}$ & -1.54 & $2.42^{*}$ \\
\hline Katsina & -0.25 & -1.42 & 1.06 & $2.12^{*}$ & 0.24 & -1.60 & 0.75 & $2.51^{*}$ \\
\hline Potiskum & 1.12 & -0.63 & 0.69 & 0.00 & $1.89^{*}$ & -0.09 & 0.94 & -0.13 \\
\hline Gusua & 0.11 & -0.27 & 0.63 & -1.06 & 1.04 & $-1.78^{*}$ & 1.00 & 0.31 \\
\hline Sokoto & 1.38 & -1.24 & 0.15 & 1.54 & 1.48 & -1.24 & -0.69 & 1.54 \\
\hline Bauchi & 0.46 & -0.33 & -0.21 & 0.84 & 1.33 & -0.27 & 0.00 & 1.59 \\
\hline Yelwa & $2.09^{*}$ & -0.03 & 0.82 & $1.65^{*}$ & $2.55^{\star}$ & $-2.14^{*}$ & $1.66^{*}$ & $2.27^{*}$ \\
\hline
\end{tabular}

The 6-month trend test for 1965-2010 also showed an increasing trend for all the stations except for Nguru. Kano, Potiskum and Yelwa showed a significantincreasing trend. For comparison, the 46 years under-study were subdivided into 21 years overlapping period. Period 1965-1985 showed a decreasing trend for all stations in both time scales. Maiduguri showed a significant decreasing trend for 3month time scale, while Nguru, Kano, Gusua and Yelwa showed a significant decreasing trend for the 6-month time scale. Only Yelwa showed a significant trend in the 1975-1995 period. Other stations showed a nonsignificant increasing and decreasing trend. Most stations showed an increasing trend in the period19852010, with Maiduguri, Nguru, Kano, Katsina and Yelwa showing a significant increase, which implies an improvement in rainfall. This is in line with the findings of Ifabiyi and Ojoye (2013) in some stations in the SudanoSahelian Ecological Zone (SSEZ) of Nigeria.

\section{CONCLUSIONS}

The foregoing discussions have shed some light on the spatial and temporal characteristics of droughts in northern Nigeria with different time scales and trends. From the analysis of the 46 years' data using Standardized Precipitation Index, there are fluctuations in the year-to-year rainfall over the study area. Stationslocated relatively close to each other have the tendency to show different pattern of annual rainfall totals in this region. Also, there could be a prevalence of more severe drought situation in Maiduguri, Kano and Bauchi. From the consideration of Mann-Kendall trend test we arrive at the conclusion that significant changes in rainfall patterns with predominantly drought in MayOctober. The yearly mean low rainfall is more correlated with the yearly drought for the 46 years under investigation. The importance of water cannot be overemphasized especially in an area such as Northern Nigeria that mainly depends on rainfall for agriculture. Therefore, agricultural organizations and disaster management parastatals should be pro-active in drought adaptation and mitigation planning as a wet year may be followed by a severe drought. A large number of further observations would be required to put some of these findings on a finer basis.

\section{REFERENCES}

Abdullahi, A. B., Iheanacho, A. C and Ibrahim, A., 2006. Econometric Analysis of the Relationship between Drought and Millet Production in the Arid Zone of Nigeria: A Case Study of Borno and Yobe States. J. Agri. Soc. Sci., 2, 170-174.

Achugbu, I. C and Anugwo, S. C., 2016. Drought Trend Analysis in Kano Using Standardized Precipitation Index, FUOYEJET, 1, 105-110.

Adefolalu, D. O., 1986. Further Aspects of Sahelian Drought as Evident From Rainfall Regime of Nigeria. Arch. Met. Geoph. Biocl., Ser. B 36, 277-295.

Akeh, L. E., Nnoli N., Gbuyiro S., Ikehua F and Ogunbo S., 2001. Meteorological Early Warning Systems (EWS) for Drought Preparedness and Drought Management in Nigeria, Nigerian Meteorological Services, Lagos, Nigeria.

Aremu, J. K and Olatunde, A. F., 2013.Drought Trends in Areas Above Latitude $8^{\circ} \mathrm{N}$ of Nigeria. Journal of Environment and Earth Science, 3, 111-119. 
Ayoade, J. O., 1988. Introduction to Climatology for the Tropics, Ibadan, Oyo state: Spectrum Books Ltd.

Buba, L. F., 2010. Spatio temporal rainfall and temperature variation in Northern Nigeria. An Unpublished PhD thesis Submitted to the Geography Dept. Bayero University Kano.

Betterton, C and Gadzama, N. M., 1987. "Effects of Drought on Public Health". In: Ecological Disasters in Nigeria: Drought and Desertification. Published by the Federal Ministry of Science and Technology, Lagos, Nigeria.

Food and Agricultural Organisation of the United Nations (FAO), 1978. Report on the Agroecological Zones Project. Vol. 1. Methodology and results for Africa. World Soil Resources Report 48. Rome.

Fleig, A. K., Tallasken, L. M., Hisdal, H., Stahl, K and Hannah, D. M., 2010. Inter-comparison of weather and circulation type classifications for hydrological drought development. Physics and Chemistry of the Earth, 35, 507-515.

Hannah, D. M., Demuth, S., Van Lanen, H. A. J., Looser, U., Prudhomme, C., Rees, G., Stahl, K and Tallaksen, L. M., 2011. Large-scale river flow archives: importance, current status and future needs. Hydrol. Process, 25, 1191-1200.

Ifabiyi, I. P., and Ojoye, S. 2013. Rainfall Trends in the Sudano-Sahelian Ecological Zone of Nigeria. Earth Science Research, 2, 194-202.

Kendall, M. G. 1975. Rank Correlation Methods. Griffin, London.

Kidson, J. W., 1977. African rainfall and its relation to the upper air circulation. Quarterly Journal Royal Meteorological Society, 106, 441-456.

Lins, H. F and Slack, J. R., 1999. Streamflow trends in the United States. Geophys Res Lett., 26, 227230.

Hisdal, H., Stahl, K., Tallaksen, L. M and Demuth, S., 2001. Have stream flow droughts in Europe become more severe or frequent? Int. J. Climatol., 21, $317-333$.

Harris, I., Jones, P. D., Osborn, T. J and Lister, D. H., 2014. Updated high-resolution grids of monthly climatic observations-the CRU TS3.10 Dataset. Int. J. Climatol., 34, 623-642

Mann, H. B., 1945. Nonparametric tests against trend. Econometrics, 13: 245-259.

McKee, T. B., Doesken, N. L and Kleist, J., 1993. The relationship of drought frequency and duration to time scales. Proc. of the $8^{\text {th }}$ Confer. on Applied Climatol. Anaheim, California.
Mavromatis, T and Stathis, D., 2011. Response of the Water Balance in Greece to Temperature and Precipitation Trends. Theoretical and Applied Climatology 104:13- 24.

Naumann, G., Dutra, E., Barbosa, P., Pappenberger, F., Wetterhall, F and Vogt, J. V., 2014. Comparison of drought indicators derived from multiple data sets over Africa. Hydrol. Earth Syst. Sci., 18, 1625-1640.

Oladipo, E. O., 1993. Some Aspects of the Spatial Characteristics of Drought in Northern Nigeria. Natural Hazards, 8, 171-188s

Olatunde, A. F and Aremu, J. K., 2013. Return Periods of Drought Intensities in Some Stations in Northern Nigeria, Journal of Environmental and Earth Science, 3, 156-162.

Sharma, T. C., 1997. A drought frequency formula. Hydrol. Sci. J., 42, 803-814.

Shahid, S and Hazarika, M. K., 2010. Groundwater droughts in the northwestern districts of Bangladesh. Water Resour. Manag., 24, 19892006.

Sheffield, J., Andreadis, K. M., Wood, E. F and Lettenmaier, D. P., 2009. Global and continental drought in the second half of the twentieth century: severity-area-duration analysis and temporal variability of large-scale events. J. Clim., 22, 1962-1981.

Sneyers, R., 1990. On the Statistical Analysis of Series of Observation. World Meteorological Organisation (WMO), Technical Note No. 143, Geneva, pp: 192.

Wang, $\square$. J., Zhang, J. Y., Shahid, S., ElMahdi, A., Ruimin, H., Zhen-xin, B and Ali, M., 2012a. Water resources management strategy for adaptation to droughts in China. Mitigation Adaptation Strategies, Global Change, 17, 923-937.

World Meteorological Organization, 2012. Standardized Precipitation Index User Guide, (Ed. M. Svoboda, M. Hayes and D. Wood.). WMO. No. 1090, Geneva.

Yue, S and Wang, C., 2004. The Mann-Kendall Test Modified by Effective Sample Size to Detect Trend in Serially Correlated Hydrological Series. Water Resources Management 18, 201-218. 
